NBER WORKING PAPER SERIES

\title{
IMMIGRANT ENTREPRENEURS AND \\ INNOVATION IN THE U.S. HIGH-TECH SECTOR
}

\author{
J. David Brown \\ John S. Earle \\ Mee Jung Kim \\ Kyung Min Lee \\ Working Paper 25565 \\ http://www.nber.org/papers/w25565 \\ NATIONAL BUREAU OF ECONOMIC RESEARCH \\ 1050 Massachusetts Avenue \\ Cambridge, MA 02138 \\ February 2019
}

We benefitted from the comments of Tom Astebro, Ina Ganguli, David Hart, Bill Kerr, Sari Pekkala Kerr, Shulamit Kahn, Megan MacGarvie, Joe Staudt, and participants in two conferences at the NBER. We thank the National Science Foundation for support (Grants 1262269 and 1719201 to George Mason University). Any opinions and conclusions expressed herein are ours only and do not necessarily reflect the views of the NSF, the U.S. Census Bureau, or the National Bureau of Economic Research. All results have been reviewed to ensure that no confidential information is disclosed. The Disclosure Review Board bypass numbers are CBDRB-2018CDAR-087, DRB-B0017-CED-20181126, and DRB-B0025-CED-20181219.

NBER working papers are circulated for discussion and comment purposes. They have not been peer-reviewed or been subject to the review by the NBER Board of Directors that accompanies official NBER publications.

(C) 2019 by J. David Brown, John S. Earle, Mee Jung Kim, and Kyung Min Lee. All rights reserved. Short sections of text, not to exceed two paragraphs, may be quoted without explicit permission provided that full credit, including $\odot$ notice, is given to the source. 
Immigrant Entrepreneurs and Innovation in the U.S. High-Tech Sector

J. David Brown, John S. Earle, Mee Jung Kim, and Kyung Min Lee

NBER Working Paper No. 25565

February 2019

JEL No. F22,F61,F66,J15,J6,L26,O3,O31

\begin{abstract}
$\underline{\text { ABSTRACT }}$
We estimate differences in innovation behavior between foreign versus U.S.-born entrepreneurs in high-tech industries. Our data come from the Annual Survey of Entrepreneurs, a random sample of firms with detailed information on owner characteristics and innovation activities. We find uniformly higher rates of innovation in immigrant-owned firms for 15 of 16 different innovation measures; the only exception is for copyright/trademark. The immigrant advantage holds for older firms as well as for recent start-ups and for every level of the entrepreneur's education. The size of the estimated immigrant-native differences in product and process innovation activities rises with detailed controls for demographic and human capital characteristics but falls for R\&D and patenting. Controlling for finance, motivations, and industry reduces all coefficients, but for most measures and specifications immigrants are estimated to have a sizable advantage in innovation.
\end{abstract}

J. David Brown

U.S. Bureau of the Census

4600 Silver Hill Road

Washington, DC 20233

j.david.brown@census.gov

John S. Earle

George Mason University

Schar School of Policy and Government

3351 Fairfax Drive, MS 3B1

Arlington VA 22201

earle@gmu.edu
Mee Jung Kim

George Mason University

Schar School of Policy and Government

3351 Fairfax Drive

Arlington VA 22201

mkim42@gmu.edu

Kyung Min Lee

George Mason University

Schar School of Policy and Government

Founders Hall

3351 Fairfax Drive

Arlington, VA 22201

klee17@gmu.edu 


\section{Introduction}

How much do immigrants contribute to innovation? Popular accounts of U.S. science, engineering, and high-tech business creation tend to cast immigrants in a starring role, and anecdotes on exceptional immigrants are easy to find, but systematic evidence is rare. A number of studies have examined immigrants as individual inventors, as employees of high-tech firms, and as scientists, engineers, and self-employed (e.g., Wadhwa et al. 2007a and 2007b, Kerr and Lincoln 2010, Hunt 2011). ${ }^{1}$

However, there have been few studies of immigrant entrepreneurs, and most of those focus on firm size and growth. ${ }^{2}$ Only Hart and Acs (2010) examine innovation measures - research and development and patenting - at the firm-level, using a survey of 1,300 "high impact" high-tech companies. ${ }^{3}$ They report little difference between firms with and without immigrant founders, but they consider a sample of firms already at the right tail of the firm performance distribution. Such data do not permit research to draw any inferences on the relative innovativeness of typical hightech businesses owned by immigrants and natives, which is the question we address in this paper.

This paper aims to contribute to understanding the innovation impact of immigrant entrepreneurship on the U.S. high-tech sector using a much larger and richer data set than those heretofore available. We analyze the Annual Survey of Entrepreneurs (ASE), a new database from the U.S. Census Bureau covering about 11,000 owners of 7,400 high-tech employer businesses based on a random sample of all nonfarm businesses. Like the well-known Surveys of Business

\footnotetext{
${ }^{1}$ Other contributions to these topics include Stephan and Levin (2001), Peri (2007), Hunt and Gauthier-Loiselle (2010), and Kerr (2013).

${ }^{2}$ As far as we can determine, the only studies of job creation by immigrant entrepreneurs using broad, representative samples are Fairlie and Lofstrom (2014) and Kerr and Kerr (2017, 2018). Brown et al. (2018) analyze immigrant status among other founder characteristics in a study of high-growth entrepreneurship. Our focus on innovation outcomes is different, but we build on this work and provide some comparisons with our approach below. A few other studies focus on particular industries, regions, or immigrant ethnicities.

${ }^{3}$ Saxenian (2002) and Wadhwa et al. (2007a) examine immigrants as owners but do not measure innovation at their firms.
} 
Owners (SBO), the ASE questionnaire contains detailed information on the four largest owners and some characteristics of the business, which provide us with control variables for measuring immigrant-native differences conditional on other characteristics including demographics, human capital, and ownership team. Unlike the SBO, however, and crucially for this paper, the ASE includes many innovation measures that form the outcome variables in our study, including reported innovation activities in both products and processes, research and development, trademarks, and patents. ${ }^{4}$

The ASE also contains a number of variables that permit more disaggregated analysis. Data on race/ethnicity permit some examination of immigrant country of origin. Data on educational attainment allow us to estimate separately by education group. We are also able to examine immigrant-native differences in the roles played by a number of factors that may be jointly determined with innovation outcomes, including ownership motivations, start-up capital, and choice of industry. For all of these variables, we are interested both in characterizing immigrant relative to native entrepreneurs and in measuring how they influence or mediate the immigrantnative entrepreneur differences in innovation performance.

The subject of our study lies at the intersection of several large areas of research. To start with, there is a voluminous literature on the economic effects of immigrants. Most of this research focuses on the consequences of immigration for native worker wages and treats immigrants as a qualitatively similar factor of production, so that immigration represents a labor supply shock to a particular region or education-experience group (e.g., Card 1990, 2001; Borjas and Doran 2015; Borjas and Monras 2017; Ottaviano and Peri 2012; Peri 2012, 2015). Other immigration research

\footnotetext{
${ }^{4}$ The random sampling for the ASE contrasts with the usual approach in "innovation surveys," including the Business Research and Development and Innovation Survey (BRDIS) in the U.S., where the sample is principally based on firms known or expected to be carrying out R\&D.
} 
focuses on the disadvantage faced by immigrants in U.S. labor markets and the extent and pace of immigrant-native convergence in wages, or "assimilation" (Borjas 1985, 2015; Chiswick, Lee, and Miller 2005; Chiswick 2009). Some studies of immigrants consider the possibility that immigrants have certain advantages and document higher rates of science, technology, engineering, and mathematics (STEM) workforce participation, patents, publication citations, and Nobel Prize winners among immigrants (Kerr and Lincoln 2010, Stephan and Levin 2001, Hunt and GauthierLoiselle 2010).

Yet much innovation takes place within firms, and our study relates to research on firmlevel Research and Development (R\&D), patenting, and other aspects of innovation. As is widely recognized, however, $R \& D$ and patents both have limitations as measures of innovation, much of which takes place without formal R\&D or patenting. Some surveys, including the Community Innovation Surveys (CIS) in Europe and the Business Research and Development and Innovation Survey (BRDIS) in the U.S., attempt to fill this gap with qualitative questions on product and process innovations (Mairesse and Mohnen 2010). These surveys have documented the incidence of such activities and demonstrated their correlation with productivity (e.g., Griffith et al. 2006, Parisi et al. 2006, Hall 2011). But the data in these studies are usually based on small samples (for example, only 5,000 receive the full questionnaire for the BRDIS) that are non-randomly selected to focus on firms with known R\&D activity. Still more importantly for our purposes, they contain no information on the firm's founders or owners.

Such characteristics have been extensively analyzed in the literature on self-employment determinants, including immigration status (e.g., Fairlie and Lofstrom 2014). But they are seldom measured for owners of firms, as distinguished from own-account (employee-less self-employed) 
workers. And a rich set of owner-founder characteristics has never before been linked to the kind of innovation measures that have become common in firm-level studies.

We find uniformly higher rates of innovation in immigrant-owned firms for 15 of 16 different measures. In most but not all cases the differences are statistically significant, and in most cases they survive detailed controls for other demographic and human capital characteristics of the entrepreneurs, as well as the size and family composition of teams. In many cases, they also remain significant in specifications controlling for start-up finance, motivations, and industry. The immigrant-native difference holds for both recent start-ups and older firms and at all levels of the entrepreneur's education. The main exception is owning a copyright or trademark, the most marketing-related activities measured here. Otherwise, the data imply a robust immigrant advantage in innovation.

The rest of the paper is organized as follows. Section 2 describes the data, and Section 3 the methods. Section 4 contains results, and Section 5 concludes.

\section{Data}

We exploit new confidential microdata from the Census Bureau's 2014 Annual Survey of Entrepreneurs (ASE). The ASE is an annual survey that supplements the Survey of Business Owners (SBO), conducted every five years, providing detailed demographic characteristics on business owners and their motivations to start a business, as well as economic characteristics of their firms. Of particular importance for this paper, it includes a rich set of innovation measures, which are the main outcome variables in our study.

The ASE sample contains non-farm businesses with at least one paid employee and receipts of $\$ 1,000$ or more. Using the Census Business Register (BR) as the sampling frame, the ASE 
sample is stratified by the 50 most populous Metropolitan Statistical Areas (MSAs), state, and the firm's number of years in business. ${ }^{5}$ The ASE sample is randomly selected, except for large companies in each stratum, which are selected with certainty based on volume of sales, payroll, or number of paid employees. The initial 2014 ASE sample was about 290,000 employer firms, and the response rate was 74 percent.

For this paper, we restrict the full ASE sample to firms in the high-tech sector as defined by the share of Science, Technology, Engineering, and Mathematics (STEM) employment in the industry. ${ }^{6}$ This represents about 5.31 percent of firm-owner observations in the ASE. We also exclude businesses where no individual owns at least 10 percent of the equity, because detailed owner information is not provided for such businesses. We drop owners who choose the same answers for every motivation question (all very important, all somewhat important, or all not important), because those answering patterns may not reflect the true intensity for each question, as well as firm-owner observations that have missing values for any of the variables used in the regressions. Our final sample consists of about 11,000 owners of 7,400 firms. We weight each owner by their ownership equity share, adjusting them to sum up to one within each firm, and we weight each firm by ASE survey weights to make the sample representative for the U.S. economy.

Our main variable of interest is an indicator for whether the owner is an immigrant, defined in the ASE as a noncitizen at birth. ${ }^{7}$ As we examine the differences in the propensity to innovate between immigrant and native owners, we control for various other owner and firm characteristics. The owner demographic characteristics consist of gender, age, race and ethnicity, type of education,

\footnotetext{
${ }^{5}$ See Foster and Norman (2016) for further details about the ASE.

${ }^{6}$ We define high-tech sector based on the share of STEM employment in the industry, using Bureau of Labor Statistics data; for the exact definition, see Goldschlag and Miranda (2016, p. 58).

${ }^{7}$ This definition reflects a change in practice relative to previous surveys such as the SBO which asked about birthplace (whether in the U.S.). The difference is in people who were born outside the U.S. but as citizens (i.e., because at least one parent was a citizen at the time). We nonetheless retain the conventional labels "immigrant" and "native" in our analysis.
} 
prior business experience, and veteran status. We also include the relationships among business owners in firms with multiple owners, whether they are couple-owned, non-couple family-owned, or multi-generation. Variable construction is similar to the procedures in Brown et al. (2018).

The ASE asks about nine different motivations for owning the business, including 1) "Best avenue for my ideas/goods/services" (Ideas); 2) "Opportunity for greater income/wanted to build wealth" (Income); 3) “Couldn't find a job/unable to find employment” (No Job); 4) "Wanted to be my own boss" (Own Boss); 5) “Working for someone else didn’t appeal to me” (Work for Self); 6) "Always wanted to start my own business" (Always Wanted); 7) "An entrepreneurial friend or family member was a role model" (Role Model); 8) "Flexible hours" (Flexible Hours); and 9) "Balance work and family" (Balance Family). These questions ask how important the reason is: not important, somewhat important, or very important. In the descriptive statistics, we collapse the variables for a particular motivation into a single variable equaling 0 if not important, 1 if somewhat important, and 2 if very important, while in the regressions we include separate dummies for somewhat important and very important for each motivation.

In some specifications we also use amount of start-up capital and 4-digit NAICS industries as controls. Amount of finance used to start or initially acquire the business includes all sources: savings, other assets, and borrowed funds. Finance is expressed as ten categorical variables from less than $\$ 5,000$ to $\$ 3$ million or more, as well as "none needed" and "don’t know".

Descriptive statistics for owner and firm characteristics are provided in Table 1. Almost 20 percent of owners of high-tech firms are immigrants, which is a bit higher than the shares of immigrants in the general population, at about 16 percent, and in self-employment, about 19 percent, based on our calculations from the 2014 Current Population Survey. The 20 percent of owners within high-tech is also higher than the 16 percent of immigrant owners in the full ASE 
sample that includes all industries, and higher than Hart and Acs' (2010) estimate for their "highimpact" sample of high-tech firms, again 16 percent. But it is lower than reported by Saxenian (2002) for immigrant ownership of high-tech firms in Silicon Valley, at 24 percent, Wadhwa et al.'s estimate of 25 percent, and Kerr and Kerr's (2017) of 24 percent. Each of these sources draws on different types of sample and definitions.

Table 1 shows the fraction of the owners in the sample having each characteristic and the fraction for immigrants and the native-born separately. We distinguish Hispanics, and among nonHispanics, whites, Asian Indians, Chinese, Other Asians, and others. Among high-tech entrepreneurs, immigrants have a higher share than natives in the Hispanic, Asian Indian, Chinese, and Other Asian populations. The largest difference is for Asian Indians, who account for 36 percent of all immigrant owners, and only 1 percent of native owners.

Table 1 also shows differences in educational attainment. Immigrants are less likely to have only a Bachelor's degree, and they are much less likely to have less than a Bachelor's degree: only about one-third as likely as natives. But more than half of immigrant owners hold an advanced degree, and they are much more likely than natives - nearly twice as likely - to have graduate education.

Do immigrants differ from natives in their reported motivations for entrepreneurship? Table 2 contains the means of the motivation variables on a 0-1-2 scale, as discussed above, for the full sample and for immigrants and natives separately. Immigrant owners report a higher propensity to cite inability to find a job as their motivation (although this motivation is uncommon for both groups in this high-tech sample), and a higher share of them say they have always wanted to own the business as a lifelong dream compared to natives. More relevant to innovation, immigrants have a slightly higher propensity to own the business because it is "the best avenue for 
their ideas, goods, or services." Overall, however, the differences in patterns of motivation appear slight.

Concerning the amount of start-up capital, Table 3 shows that the immigrant-native differences exhibit a J-shaped relationship such that immigrants are slightly more likely to be in the lowest category of start-up capital and substantially more likely to be in the highest categories. Immigrants are 43 percent more likely than natives to have finance in the range $\$ 1-3 \mathrm{mln}$, and for more than $\$ 3 \mathrm{mln}$ they are 60 percent more likely.

We also consider firm age as a possible correlate of innovation behavior. Table 3 shows that immigrants typically own younger firms (here defined as five years or less since first hiring) than do natives. Just over half of the immigrant-owned high-tech firms started up within the previous five years, while 63 percent of the native-owned firms are older than 5 years.

Nearly three-quarters of the firms in this high-tech sample are in two four-digit NAICS industries: Architectural, Engineering, and Related Services (5413), and Computer Systems Design and Related Services (5415). As shown in Table 4, immigrant-owned firms are disproportionately located in the latter and under-represented in the former. No other industry accounts for as much as 3 percent of the sample, and the immigrant-native differences in all these other industries are small and statistically insignificant. ${ }^{8}$

Our outcome variables include detailed innovation, research and development (R\&D), and intellectual property measures. The ASE asks whether the business conducted twelve different product or process innovation activities in the last three years (2012-2014). We create a binary variable for innovation to indicate whether a firm conducted any product or process innovation in the last three years. We also calculate an innovation count by summing the number of product and

\footnotetext{
${ }^{8}$ While there are 15 4-digit high-tech industries, some sectors have too few observations for the results to be disclosed.
} 
process innovation activities. We make binary indicator variables for each type of product and process innovation activities. Product innovations include 1) sold a new good or service that no other business has ever offered before; 2) sold a new good or service that this business has never offered before; 3 ) improved a good or service's performance by making changes in materials, equipment, software, or other components; 4) developed a new use for a good or service; 5) added a new feature to a good or service; and 6) made it easier for customers to use a good or service. Process innovations include 1) applied a new way of purchasing, accounting, computing, maintenance, inventory control, or other support activity; 2) reduced costs by changing the way a good or service was distributed; 3) upgraded a technique, equipment, or software to significantly improve a good or service; 4) made a significant improvement in a technique or process by increasing automation, decreasing energy consumption, or using better software; 5) decreased production costs by improving the materials, software, or other components; and 6) changed a delivery method to be faster or more reliable.

Table 5 shows means of these innovation activities. About 69 percent of firms report they conducted at least one innovation, and the average number of innovation types is 3.6 in our hightech sample. Although not shown in the table, the most common product innovation is improving a good or service's performance (44.3 percent) and making it easier for customers to use good or service (41.7 percent), and upgrading a technique, equipment, or software to significantly improve a good or service (50.9 percent) is the most frequent process improvement.

The ASE asks business owners whether their business carried out seven different R\&D activities in 2014. We create an indicator for whether the business conducted any of these types of R\&D. We also construct binary variables for each of the activities separately. We classify the following activities as "Applied R\&D:" 1) conducted work that might lead to a patent; 2) 
developed and tested prototypes that were derived from scientific research or technical findings; and 3) applied scientific or technical knowledge in a way that has never been done before. We classify "Basic R\&D" as activities that 1) produced findings that could be published in academic journals or presented at scientific conferences; 2) created new scientific research or technical solutions that can be generalized to other situations; 3) conducted work to discover previously unknown scientific facts, structures, or relationships; and 4) conducted work to extend the understanding of scientific facts, relationships or principles in a way that could be useful to others. In Table 5, 23.1 percent of firms conducted at least one of these R\&D activities in 2014, and the most frequent $R \& D$ activity is work that might lead to a patent. In general, the average rate of conducting R\&D activities is lower than the innovation activities above. ${ }^{9}$

The last set of outcome variables concerns intellectual property. The ASE asks whether the business owns one or more of each of the following in 2014: copyright, trademark, patent (granted), and patent (pending). We use a dummy variable for owning either a copyright or trademark, and another for ownership of a patent granted or pending. Looking at Table 5, about 20 percent of firms within the high-tech sector own a copyright or trademark, while less than 5 percent of firms own patents either pending or granted.

A striking result from Table 5 is the consistently stronger innovation performance of immigrant- compared to native-owned firms. Immigrants are more likely to carry out 15 of the 16 measures of innovation. The exceptions are copyrights and trademarks, where native-owned firms have the advantage. Examining the statistical significance of these differences and how they change when other variables are taken into account are the subjects of the next sections.

\footnotetext{
9 The lower R\&D propensity could be partly due to the fact that the R\&D questions are about activity in just one year, while the innovation activities are over three years.
} 


\section{Methods}

We use the sample of owners and firms to estimate a series of regression models for each firm-level innovation outcome conditional on the owner's immigrant status. To take into account firms with multiple owners, we weight firm-owner observations by ownership shares. Given that the ASE is a random sample of employer businesses drawn from the BR, this implies our results are representative of the firm population. We use a linear probability model for binary innovation outcomes and a Poisson regression model for innovation count. Standard errors are clustered at the firm level. Our base specification is:

$$
Y_{i j}=\beta M_{i j}+f\left(A g e_{j}\right)+u_{i j}
$$

where $M_{i j}$ is an immigrant owner indicator for owner $i$ of firm $j$. The dependent variables are each type of product innovation, process innovation, R\&D activity, and intellectual property. Since businesses are of different ages, and innovation may be correlated with firm age, in every specification (including the base) we control for a quadratic function of firm age, $f\left(A g e_{j}\right)$. The coefficient on the immigrant owner indicator $(\beta)$ captures the differences in innovation outcomes, essentially the raw gaps controlling only for firm age, between immigrant and native owners.

The purpose here is simply to describe differences in innovation behavior between immigrant and native owners. Just as in an analysis of gender differences in wages, for example, there is no issue of causality: we do not interpret the results as the impact of turning a random native into an immigrant (just as the interpretation placed on a female coefficient is not the impact of changing a male into a female). But it is also of interest to know whether there are observable differences that might account for the raw gap estimated by equation (1). For this purpose, we estimate another specification with owner characteristic controls as:

$$
Y_{i j}=\beta M_{i j}+f\left(A g e_{j}\right)+X_{i j} \gamma+u_{i j}
$$


where $\boldsymbol{X}_{i j}$ is a vector of characteristics of owner $i$ of firm $j$. The vector includes demographic variables (gender, age, and race/ethnicity), proxies for human capital (education, veteran, and prior business), and ownership team variables (size and family relationships). Arguably, these variables are pre-determined with respect to innovation behavior. The $\beta$ estimated from equation (2) is a measure of the innovation gap between native and immigrant owners adjusted for personal characteristics.

In addition, immigrants may differ from natives in ways that are less clearly exogenous and indeed may be jointly determined with innovation: motivations, start-up capital, and industries as shown in the following specification:

$$
Y_{i j}=\beta M_{i j}+f\left(A g e_{j}\right)+X_{i j} \gamma+Q_{i j} \alpha_{Q}+K_{j} \alpha_{K}+S_{j} \alpha_{S}+u_{i j}
$$

where $Q_{i j}$ is the set of motivation variables, $K_{j}$ is the set of vectors of the amount of start-up finance categories, and $S_{j}$ is the set of vectors of 4-digit NAICS industry dummies. Most small business owners start their businesses due to non-pecuniary motives with no intention to grow or innovate (Hurst and Pugsley 2011). Given the selection process to come to the U.S., immigrant owners may have different motivations to own their businesses, which may influence their innovation outcomes. The importance of access to finance for business start-ups is well documented in the literature (e.g. Evans and Jovanovic 1989; Evans and Leighton 1989), and immigrant-owned businesses also tend to have higher start-up capital amounts than those owned by natives (Fairlie 2012). Higher start-up finance among immigrant owners may account for the differences in innovation outcomes between immigrant and native owners. Finally, immigrants may select into specific industries. Immigrants may be more or less likely to own businesses in industries with more innovation activities (e.g., certain parts of the high-tech sector), and this specification controls for this choice, comparing immigrants and natives within industries. 
We also examine the heterogeneity of relative innovation performance of immigrant owners along three dimensions: education categories, race/ethnicity, and firm age. The literature on high-skilled immigrants (those with bachelor's degree or more) provides evidence that they are more likely to hold patents (e.g. Hunt and Gauthier-Loiselle 2010; Kerr and Lincoln 2010). However, the role of education in immigrant entrepreneurship has been less studied. We therefore examine heterogeneous innovation outcomes by owner education, distinguishing three groups: those with less than a bachelor's degree, those with a bachelor's degree, and those with advanced degrees.

Previous research has also examined immigrants by country of origin. Saxenian (2002) and Wadhwa et al. (2007) report higher shares of Indian and Chinese immigrants (Asian) in high-tech sectors, for example, showing an especially high share for Indians. Although the ASE does not ask for country of origin, we use race/ethnicity to reflect the region of origin. We distinguish Hispanics, and among non-Hispanics, whites, Asian Indians, Chinese, Other Asians, and others.

Finally, we investigate whether the relative innovation performance of immigrant owners varies with the age of the firm. Although all specifications control for firm age, it is interesting to ask whether any immigrant advantage in innovation holds only during the early, entrepreneurial phase of a firm's development or also during more mature phases. For this purpose, we permit the immigrant owner coefficient to vary based on whether the firm is five or fewer years old or not.

The specification for heterogeneous immigrant contributions is:

$$
Y_{i j}=Z_{i j} M_{i j} \delta+f\left(A_{g e}\right)+X_{i j} \gamma+\varepsilon_{i j}
$$

where $Z_{i j} M_{i j}$ are the interaction terms between owner characteristics $Z_{i j}$ (education categories, race/ethnicity, or firm age) and the immigrant indicator $M_{i j}$ for owner $i$ of firm $j$. 


\section{Results}

Tables 6 and 7 display regression results for each measure of innovation using the three specifications described above: (1) base (no controls other than firm age), (2) adding demographic controls, and (3) adding motivations, finance, and industry controls. The different types of product and process innovation activities, including the dummy for any activity and the count of the number of activities are in Table 6 . Table 7 contains the different types of $R \& D$ as well as the intellectual property measures (copyright or trademark, and patent granted or pending).

The results show that immigrant-owned firms have higher propensities to conduct product and process innovation as well as $\mathrm{R} \& \mathrm{D}$ activity. The inclusion of demographic controls generally raises the immigrant association with innovation activities, suggesting that immigrant owners tend on average to have other characteristics that are negatively associated with product and process innovation. Demographic controls attenuate the immigrant associations with R\&D activities, however.

Differing motivations, levels of start-up capital, and/or choices of industry explain much of the immigrant association with innovation activities, but not R\&D activities, as evidenced by the significant attenuation of the immigrant coefficients when including those controls in the innovation activity regressions and more modest attenuation or even intensification when adding them to the R\&D regressions. ${ }^{10}$

The immigrant effect is positive across all R\&D activities, though after adding controls it becomes insignificant for producing publishable findings. Immigrant ownership is generally not

\footnotetext{
${ }^{10}$ In results not shown here, the effect varies considerably across innovation measures. It is especially strong for developing a new use for a good or service. Immigrants have a higher propensity to develop goods or services that no other firm offers, but not goods or services that are new only to this firm. The former is a more radical form of innovation. Among process innovations, the immigrant association is insignificant for new way to support activity and upgrading a technique/equipment/software, while it is quite strong for increased automation/used better software.
} 
associated with owning intellectual property, and the association is actually negative and significant in two of the three trademark specifications. The only positive and significant association is with patent pending in the specification without controls.

To investigate whether the immigrant advantage varies with firm age, we permit the immigrant indicator to vary with firm age in two categories: up to 5 years old and more than 5 years old. Regression estimates are shown in Table 8 . The propensity to engage in innovation activities is similar for both young and older firms owned by immigrants. The point estimates are higher for immigrant-owned older firms for R\&D activity and ownership of intellectual property. Among native-owned firms, the propensity to conduct R\&D activities is higher for young firms, but for innovation activities a positive young firm effect disappears once adding controls, and differences are insignificant for intellectual property ownership. Both immigrant-owned firm age categories exhibit higher propensities to engage in innovation and R\&D than either native-owned firm age category across most specifications, while differences are generally insignificant for intellectual property ownership. These results suggest the immigrant advantage is maintained or even increases with firm age.

Regarding variation in the immigrant effect with educational attainment, we specify the equation so that the reference category is natives with less than a bachelor's degree. As shown in Table 9, the propensity to carry out any product or process innovation activity is increasing in education for native-owned firms, but not immigrant-owned firm. For innovation count, there is a higher association with innovation for native-owned firms where the owner has at least a bachelor's degree, but there is little difference between bachelor's and advanced degrees. The coefficients exhibit a U-shape with educational attainment for immigrant-owned businesses. Firms with advanced degree-immigrants have the highest innovation count propensities and those with 
less than bachelor's degree natives have the lowest. Having a graduate degree is strongly associated with R\&D activity for both native- and immigrant owned-firms, and the immigrant effects within the graduate degree category are larger. For copyrights and patents, it is firms with native owners with graduate degrees that distinguish themselves. Across all innovation measures, the immigrant advantage is generally largest for owners with less than a bachelor's degree.

Finally, we use race and ethnicity to examine differences in the immigrant innovation advantage across region of origin. Results with white natives as the reference group are shown in Table 10. Sample sizes get thin, so results are less precisely estimated. One striking result is that firms owned by Asian Indians, despite their high prevalence in the sample, tend to produce less of all types of innovation when full controls are included.

\section{Conclusion}

Much of the research on immigration assumes that natives and immigrants are similar factors of production, in various cases conditional on geographical region, education, and experience. An influx of immigrants is analyzed as a labor supply shock to the region or the skill group. Another large and long-standing body of research focuses on the difficulties immigrants face in adjusting to their new environments, measuring rates of "assimilation," usually defined as degree of convergence to otherwise similar native workers.

A much smaller literature takes a different approach, treating immigrants as potentially advantaged rather than either similar or disadvantaged relative to natives. Much of this research has focused on individual immigrants in science, the STEM workforce, and entrepreneurship. With some variation, the results suggest disproportionate contributions to some measures of innovation, with immigrants more likely to hold patents, work in STEM, achieve high citation indices, and 
receive Nobel Prizes. (Hunt 2011; Kerr 2013; Kahn and MacGarvie 2016). One interpretation of these results is that immigrants self-select from the right tail of the ability distribution and perhaps that the distribution has a fatter right tail than that of natives (Kahn et al. 2018).

Our premise is similar to this literature, asking whether immigrants tend to be more innovative than natives. But our focus is on firms founded and operated by immigrants in comparison to those owned by natives. There has been a lot of "hype" about immigrant entrepreneurs in the U.S. high-tech sector, but relatively little evidence on the extent to which they contribute disproportionately to innovation. This paper provides such evidence drawing upon a large representative sample of high-tech businesses and using detailed information on owner characteristics, motivations, and start-up capital, as well as an extensive set of innovation measures. We focus on the high-tech sector because of its prominence in U.S. growth.

The results suggest higher innovation activities by immigrants for nearly all the innovation measures we are able to analyze. The measures range from detailed product and process innovation, to several forms of $\mathrm{R} \& \mathrm{D}$, to intellectual property rights associated with innovation, including patents. The only measures where immigrants have notably lower performance compared with natives is for copyrights and trademarks.

Immigrant entrepreneurs tend to be much better educated than their native counterparts in the high-tech sector, on average, but the immigrant advantage persists when we control for education and other owner characteristics, and we find an immigrant advantage at all levels of education, again with the exception of copyright or trademark. Immigrant entrepreneurs also tend to operate younger firms, and while we find firm age is negatively correlated with innovation, again the immigrant advantage exists when we control for firm age (as we do in all specifications). Moreover, we find an immigrant advantage in innovation for both younger and older firms. 
Future research could expand on these findings by broadening both the population under consideration and the set of outcome variables to be analyzed. A sample including other industries could shed light on the relative innovativeness of immigrant entrepreneurs outside of the high-tech sector. Rather than confining attention to the nativity of individual owners, the analysis could be extended to the possible effects of combining immigrant and native human capital within entrepreneurial teams. Finally, the roles of immigrant entrepreneurs in job creation and productivity growth could be examined in a broader assessment of the contributions of immigrants to innovative entrepreneurship in the U.S. We hope to report our findings on these issues in the near future. 


\section{References}

Borjas, George J. 1985. "Assimilation, Changes in Cohort Quality, and the Earnings of Immigrants." Journal of Labor Economics 3 (4): 463-489.

Borjas, George J. 2015. "The Slowdown in the Economic Assimilation of Immigrants: Aging and Cohort Effects Revisited Again." Journal of Human Capital 9 (4): 483-517.

Borjas, George J., and Kirk B. Doran. 2015. "Cognitive Mobility: Labor Market Responses to Supply Shocks in the Space of Ideas." Journal of Labor Economics 33 (1): 109-145.

Borjas, George J., and Joan Monras. 2017. "The Labour Market Consequences of Refugee Supply Shocks." Economic Policy 32 (91): 361-413.

Brown, J. David, John S. Earle, Mee Jung Kim, Kyung Min Lee. 2018. "High-Growth Entrepreneurship.” IZA Discussion Paper No. 11662.

Card, David. 1990. "The Impact of the Mariel Boatlift on the Miami Labor Market." ILR Review 43 (2): 245-257.

Card, David. 2001. "Immigrant inflows, native outflows, and the local labor market impacts of higher immigration." Journal of Labor Economics 19 (1): 22-64.

Chiswick, Barry R., Yew Liang Lee, and Paul W. Miller. 2005. "A Longitudinal Analysis of Immigrant Occupational Mobility: A Test of the Immigrant Assimilation Hypothesis." International Migration Review 39 (2): 332-353.

Chiswick, Carmel U. 2009. "The Economic Determinants of Ethnic Assimilation." Journal of Population Economics 22 (4): 859.

Evans, David S., and Boyan Jovanovic. 1989. "An Estimated Model of Entrepreneurial Choice under Liquidity Constraints." Journal of Political Economy 97(4): 808-827.

Evans, David S., and Linda S. Leighton. 1989. "Some Empirical Aspects of Entrepreneurship." American Economic Review 79(3): 519-535.

Fairlie, Robert W. 2012. "Immigrant Entrepreneurs and Small Business Owners, and Their Access to Financial Capital." Small Business Administration: 1-46.

Fairlie, Robert W., and Magnus Lofstrom. 2014. "Immigration and Entrepreneurship." In Handbook of the Economics of International Migration. Vol. 1B. (edited by Barry Chiswick and Paul Miller). North Holland: 877-911.

Foster, Lucia, and Patrice Norman. 2016. "The Annual Survey of Entrepreneurs: An Introduction.” CES Discussion Paper 15-40R. 
Ganguli, Ina, Shulamit Kahn, and Megan MacGarvie. 2018. "Introduction to The Role of Immigrants and Foreign Students in Science, Innovation, and Entrepreneurship." In The Role of Immigrants and Foreign Students in Science, Innovation, and Entrepreneurship. (edited by Ina Ganguli, Shulamit Kahn, Megan MacGarvie). University of Chicago Press. (forthcoming).

Goldschlag, Nathan, and Javier Miranda, 2016, "Business Dynamics Statistics of High Tech Industries." CES Discussion Paper 16-55.

Griffith, Rachel, Elena Huergo, Jacques Mairesse, and Bettina Peters. 2006. "Innovation and Productivity across Four European Countries." Oxford Review of Economic Policy 22 (4): 483498.

Hall, Bronwyn H. 2011. Innovation and Productivity. National Bureau of Economic Research. No. w17178.

Hart, David M., and Zoltan J. Acs. 2011. "High-tech Immigrant Entrepreneurship in the United States." Economic Development Quarterly 25 (2): 116-129.

Hunt, Jennifer. 2011. "Which Immigrants are most Innovative and Entrepreneurial? Distinctions by Entry Visa." Journal of Labor Economics 29 (3): 417-457.

Hunt, Jennifer, and Marjolaine Gauthier-Loiselle. 2010. "How Much Does Immigration Boost Innovation?" American Economic Journal: Macroeconomics 2(2): 31-56.

Hurst, Erik, and Benjamin W. Pugsley. 2011. "What Do Small Businesses Do?" Brookings Papers on Economic Activity: 73.

Kahn, Shulamit, and Megan J. MacGarvie. 2016. "How Important is US Location for Research in Science?" Review of Economics and Statistics 98 (2): 397-414.

Kerr, William R. 2013. High-skilled Immigration, Innovation, and Entrepreneurship: Empirical Approaches and Evidence. National Bureau of Economic Research. No. w19377.

Kerr, William R., and Sari Pekkala Kerr. 2017. "Immigrant Entrepreneurs." In Measuring Entrepreneurial Businesses: Current Knowledge and Challenges. (edited by John Haltiwanger, Erik Hurst, Javier Miranda, and Antoinette Schoar). Chicago: University of Chicago Press.

Kerr, Sari Pekkala, and William R. Kerr. 2018. "Immigrant Entrepreneurship in America: Evidence from the Survey of Business Owners 2007 \& 2012." National Bureau of Economic Research. No. 24494.

Kerr, William R., and William F. Lincoln. 2010. "The Supply Side of Innovation: H-1B Visa Reforms and US Ethnic Invention." Journal of Labor Economics 28(3): 473-508.

Mairesse, Jacques, and Pierre Mohnen. 2010. "Using Innovation Surveys for Econometric Analysis." In Handbook of the Economics of Innovation, Vol. 2, p. 1129-1155. North-Holland. 
Ottaviano, Gianmarco IP, and Giovanni Peri. 2012. "Rethinking the Effect of Immigration on Wages." Journal of the European Economic Association 10 (1): 152-197.

Parisi, Maria Laura, Fabio Schiantarelli, and Alessandro Sembenelli. 2006. "Productivity, Innovation and R\&D: Micro Evidence for Italy." European Economic Review 50 (8): 2037-2061.

Peri, Giovanni. 2007. "Higher Education, Innovation and Growth." In Education and Training in Europe. (edited by Giorgio Brunello, Pietro Garibaldi, and Etienne Wasmer). Oxford: Oxford University Press.

Peri, Giovanni. 2012. "The Effect of Immigration on Productivity: Evidence from US States." Review of Economics and Statistics (1): 348-358.

Peri, Giovanni, Kevin Shih, and Chad Sparber. 2015. "STEM Workers, H-1B Visas, and Productivity in US Cities." Journal of Labor Economics 33 (1): 225-255.

Saxenian, AnnaLee. 2002. "Silicon Valley's New Immigrant High-Growth Entrepreneurs." Economic Development Quarterly 16(1): 20-31.

Stephan, Paula E., and Sharon G. Levin. 2001. "Exceptional Contributions to US Science by the Foreign-Born and Foreign-Educated." Population Research and Policy Review 20 (1-2): 59-79.

Wadhwa, Vivek, AnnaLee Saxenian, Ben A. Rissing, and Gary Gereffi. 2007a. "America's New Immigrant Entrepreneurs: Part I." Duke Science, Technology \& Innovation Paper No. 23. Available at SSRN: https://ssrn.com/abstract=990152

Wadhwa, Vivek, Ben Rissing, AnnaLee Saxenian, and Gary Gereffi. 2007b. "Education, entrepreneurship and immigration: America's new immigrant entrepreneurs, Part II." Available at SSRN: https://ssrn.com/abstract=991327 or http://dx.doi.org/10.2139/ssrn.991327 
Table 1. Descriptive Statistics: Demographic Characteristics

\begin{tabular}{lccc}
\hline VARIABLES & All & Immigrant & Native \\
\hline Immigrant & 19.79 & 100.00 & 0.00 \\
Race/ethnicity & & & \\
$\quad$ Hispanic & 3.59 & 6.81 & 2.79 \\
$\quad$ White (non-Hispanic) & 80.55 & 33.58 & 92.14 \\
$\quad$ Asian Indian (non-Hispanic) & 7.93 & 36.46 & 0.89 \\
$\quad$ Chinese (non-Hispanic) & 2.72 & 10.38 & 0.83 \\
Other Asian (non-Hispanic) & 2.80 & 9.52 & 1.14 \\
$\quad$ Other Minority (non-Hispanic)* & 2.41 & 3.25 & 2.20 \\
Education & & & \\
$\quad$ Less than Bachelor's Degree & 23.71 & 9.55 & 27.21 \\
$\quad$ Bachelor's Degree & 43.55 & 37.20 & 45.11 \\
$\quad$ Graduate Degree & 32.74 & 53.24 & 27.68 \\
\hline Observations & 11,000 & 2,000 & 9,000 \\
\hline
\end{tabular}

Note: These are percentages of owners by characteristics from the ASE high-tech sample. Non-Hispanic African Americans are included with Other Minority (non-Hispanic) because the number of immigrants in this category is too small to disclose. 
Table 2. Descriptive Statistics: Motivations for Owning the Business

\begin{tabular}{lccc}
\hline VARIABLES & All & Immigrant & Native \\
\hline Idea & 1.49 & 1.51 & 1.48 \\
Income & 1.49 & 1.46 & 1.50 \\
No Job & 0.10 & 0.14 & 0.09 \\
Own Boss & 1.47 & 1.35 & 1.50 \\
Work for Self & 0.90 & 0.79 & 0.92 \\
Always Wanted to Own Business & 1.18 & 1.32 & 1.14 \\
Role Model & 0.62 & 0.63 & 0.62 \\
Flexible Hours & 1.26 & 1.21 & 1.27 \\
Balance Work/Family & 1.28 & 1.28 & 1.28 \\
\hline Observations & 11,000 & 2,000 & 9,000
\end{tabular}

Note: These are means of motivation variables measured on a scale where 0 is not important, 1 is somewhat important, and 2 is very important. 
Table 3. Descriptive Statistics: Start-up Capital and Firm Age

\begin{tabular}{lccc}
\hline VARIABLES & All & Immigrant & Native \\
\hline Finance & & & \\
No capital needed & 10.73 & 9.27 & 11.09 \\
Capital under 5k & 26.35 & 31.05 & 25.19 \\
$5 \mathrm{k}$ to 10k & 11.54 & 12.80 & 11.22 \\
$10 \mathrm{k}$ to 25k & 14.06 & 14.98 & 13.83 \\
25k to 50k & 7.77 & 7.70 & 7.79 \\
$50 \mathrm{k}$ to 100k & 6.75 & 5.73 & 7.00 \\
100k to 250k & 5.80 & 5.14 & 5.96 \\
250k to 1m & 3.50 & 3.85 & 3.42 \\
1m to 3m & 1.17 & 1.54 & 1.08 \\
3m and more & 0.50 & 0.72 & 0.45 \\
Don't know start-up capital & 11.84 & 7.21 & 12.98 \\
Firm age & & & \\
Young (age<=5) & 39.66 & 50.50 & 36.99 \\
$\quad$ Old (age $>5$ ) & 60.34 & 49.50 & 63.01 \\
\hline Observations & 11,000 & 2,000 & 9,000 \\
\hline Nor
\end{tabular}

Note: These are percentages of owners by characteristics from the ASE high-tech sample. 
Table 4. High-Tech Industries: Definition and Composition

\begin{tabular}{lccc}
\hline High-Tech Industry & $\begin{array}{c}\text { Share of } \\
\text { Sample }\end{array}$ & $\begin{array}{c}\text { Share of } \\
\text { Immigrants }\end{array}$ & $\begin{array}{c}\text { Share of } \\
\text { Natives }\end{array}$ \\
\hline Oil \& Gas Extraction (2111) & 2.29 & $\mathrm{D}$ & $\mathrm{D}$ \\
Pharmaceutical \& Medicine Manufacturing (3254) & 0.54 & 17.63 & 82.37 \\
Computer \& Peripheral Equipment Manufacturing & 0.39 & $\mathrm{D}$ & $\mathrm{D}$ \\
(3341) & & & $\mathrm{D}$ \\
Communications Equipment Manufacturing (3342) & 0.44 & $\mathrm{D}$ & 81.59 \\
Semiconductor and Other Electronic Component & 1.01 & 18.41 & \\
Manufacturing (3344) & & & 83.06 \\
Navigational, Measuring, Electromedical, \& Control & 1.38 & 16.94 & \\
Instruments Manufacturing (3345) & & & $\mathrm{D}$ \\
Aerospace Product \& Parts Manufacturing (3364) & 0.32 & $\mathrm{D}$ & 76.75 \\
Software Publishers (5112) & 1.44 & 23.25 & 79.00 \\
Wired Telecommunications Carriers (5171) & 0.71 & 21.00 & $\mathrm{D}$ \\
Other Telecommunications (5179) & 0.94 & $\mathrm{D}$ & 82.33 \\
Data Processing, Hosting, \& Related Services (5182) & 2.46 & 17.67 & 82.73 \\
Other Information Services (5191) & 2.17 & 17.27 & 87.81 \\
Architectural, Engineering, \& Related Services (5413) & 39.07 & 12.19 & 71.45 \\
Computer Systems Design \& Related Services (5415) & 43.67 & 28.55 & 76.82 \\
Scientific Research \& Development Services (5417) & 3.18 & 23.18 & \\
\hline
\end{tabular}

Notes: "D" means suppressed to ensure that no confidential information is disclosed. 
Table 5. Descriptive Statistics: Innovation Measures

\begin{tabular}{lrrr}
\hline VARIABLES & All & Immigrant & Native \\
\hline Innovation Activities & & & \\
Innovation dummy & 69.39 & 72.01 & 68.74 \\
Innovation count & 3.58 & 3.89 & 3.50 \\
Production Innovation dummy & 56.90 & 60.55 & 56.00 \\
Process Innovation dummy & 60.30 & 61.61 & 59.98 \\
R\&D Activities & & & \\
R\&D activity (any type) & 23.11 & 28.02 & 21.90 \\
Work toward patent & 13.40 & 16.98 & 12.52 \\
Developed prototypes & 13.29 & 17.18 & 12.34 \\
Applied scientific/technic. knowled. & 11.16 & 15.26 & 10.14 \\
Produced publishable findings & 9.68 & 12.55 & 8.97 \\
Created generalizable research & 11.34 & 15.73 & 10.26 \\
Work to discover scientific facts & 6.02 & 9.27 & 5.22 \\
Work to extend understanding of scientific facts & 10.51 & 14.37 & 9.56 \\
Intellectual Property & & & \\
Copyright or Trademark & 20.03 & 16.79 & 20.83 \\
Patent granted or pending & 6.60 & 8.50 & 6.13 \\
\hline Observations & 11,000 & 2,000 & 9,000 \\
\hline
\end{tabular}

Note: These are percentages of owners by innovation measures (except for innovation count) from the ASE hightech sample. 
Table 6. Product and Process Innovation by Immigrants

\begin{tabular}{lccc}
\hline \multicolumn{1}{c}{ VARIABLES } & Base & + Demographics & $\begin{array}{c}\text { + Motivations, } \\
\text { Finance \& Industry }\end{array}$ \\
\hline Innovation Activities & & & \\
Innovation dummy & 2.883 & 4.669 & 2.539 \\
Innovation count & $(1.469)$ & $(1.788)$ & $(1.748)$ \\
& 0.090 & 0.146 & 0.081 \\
Product Innovation & $(0.031)$ & $(0.036)$ & $(0.036)$ \\
& 3.488 & 6.438 & 3.055 \\
Process Innovation & $(1.588)$ & $(1.921)$ & $(1.870)$ \\
& 1.632 & 4.606 & 2.887 \\
Observations & $(1.582)$ & $(1.964)$ & $(1.950)$ \\
\hline
\end{tabular}

Note: Results from LPM estimation of Equation (1) at firm age 1. Coefficients and standard errors are multiplied by 100 for ease of reading. All regressions include firm age and age squared. The second column ("+Demographics") includes demographic variables (gender, age, and race/ethnicity), proxies for human capital (education, veteran, and prior business), and ownership team variables (size and family relationships). The last column includes motivations from Table 2, start-up finance from Table 3, and 4-digit NAICS industry dummies from Table 4. Standard errors clustered by firm are in parentheses. 
Table 7. R\&D, Copyright, Trademark, and Patents by Immigrants

\begin{tabular}{lccc}
\hline \multicolumn{1}{c}{ VARIABLES } & Base & + Demographics & $\begin{array}{c}\text { + Motivations, } \\
\text { Finance \& Industry }\end{array}$ \\
\hline R\&D activity & & & \\
R\&D activity (any type) & 5.580 & 4.653 & 3.720 \\
Work toward patent & $(1.426)$ & $(1.828)$ & $(1.767)$ \\
& 3.714 & 2.886 & 2.297 \\
Developed prototypes & $(1.175)$ & $(1.514)$ & $(1.450)$ \\
& 4.729 & 3.885 & 3.169 \\
Applied scientific/technic. & $(1.180)$ & $(1.565)$ & $(1.492)$ \\
knowledge & 4.528 & 3.698 & 3.358 \\
Produced publishable findings & $(1.114)$ & $(1.453)$ & $(1.407)$ \\
& 3.342 & 1.667 & $(1.267)$ \\
Created generalizable research & $(1.019)$ & $(1.334)$ & 3.654 \\
& 4.772 & 4.102 & $(1.399)$ \\
Work to discover scientific & $(1.122)$ & $(1.451)$ & 3.009 \\
facts & 3.749 & 2.754 & $(1.103)$ \\
Work to extend understanding & $(0.895)$ & $(1.150)$ & 3.346 \\
of scientific facts & 4.574 & 3.062 & $(1.341)$ \\
Intellectual Property & $(1.084)$ & $(1.405)$ & -2.201 \\
Copyright or Trademark & & & $(1.555)$ \\
Patent granted or pending & -3.343 & -0.150 & -0.330 \\
& $(1.199)$ & $(1.592)$ & $(1.009)$ \\
\hline Observations & 2.362 & 0.035 & 11,000 \\
\hline Ne: Resus & $(0.858)$ & $(1.051)$ & \\
\hline
\end{tabular}

Note: Results from LPM estimation of Equation (1) at firm age 1. Coefficients and standard errors are multiplied by 100 for ease of reading. All regressions include firm age and age squared. The second column ("+ Demographics") includes demographic variables (gender, age, and race/ethnicity), proxies for human capital (education, veteran, and prior business), and ownership team variables (size and family relationships). The last column includes motivations from Table 2, start-up finance from Table 3, and 4-digit NAICS industry dummies from Table 4. Standard errors clustered by firm are in parentheses. 
Table 8. Innovation by Immigrants - Firm Age Heterogeneity

\begin{tabular}{|c|c|c|c|}
\hline VARIABLES & Base & + Demographics & $\begin{array}{c}\text { + Motivations, } \\
\text { Finance } \& \text { Industry }\end{array}$ \\
\hline \multicolumn{4}{|l|}{ Innovation dummy } \\
\hline Old*Immigrant & $\begin{array}{l}4.086 \\
(2.022)\end{array}$ & $\begin{array}{l}4.630 \\
(2.230)\end{array}$ & $\begin{array}{l}2.700 \\
(2.147)\end{array}$ \\
\hline Young*Native & $\begin{array}{c}3.982 \\
(1.308)\end{array}$ & $\begin{array}{c}1.099 \\
(1.379)\end{array}$ & $\begin{array}{c}1.298 \\
(1.342)\end{array}$ \\
\hline Young*Immigrant & $\begin{array}{c}5.385 \\
(2.032)\end{array}$ & $\begin{array}{l}4.518 \\
(2.393)\end{array}$ & $\begin{array}{c}3.530 \\
(2.341)\end{array}$ \\
\hline \multicolumn{4}{|l|}{ Innovation count } \\
\hline Old*Immigrant & $\begin{array}{c}0.127 \\
(0.042)\end{array}$ & $\begin{array}{c}0.157 \\
(0.046)\end{array}$ & $\begin{array}{c}0.084 \\
(0.044)\end{array}$ \\
\hline Young*Native & $\begin{array}{c}0.105 \\
(0.028)\end{array}$ & $\begin{array}{c}0.004 \\
(0.029)\end{array}$ & $\begin{array}{l}-0.004 \\
(0.027)\end{array}$ \\
\hline Young*Immigrant & $\begin{array}{c}0.164 \\
(0.043)\end{array}$ & $\begin{array}{c}0.122 \\
(0.050)\end{array}$ & $\begin{array}{c}0.069 \\
(0.048)\end{array}$ \\
\hline \multicolumn{4}{|c|}{ R\&D activity (any type) } \\
\hline Old*Immigrant & $\begin{array}{c}8.592 \\
(1.968)\end{array}$ & $\begin{array}{c}7.051 \\
(2.211)\end{array}$ & $\begin{array}{c}5.337 \\
(2.117)\end{array}$ \\
\hline Young*Native & $\begin{array}{c}3.665 \\
(1.195)\end{array}$ & $\begin{array}{c}3.021 \\
(1.250)\end{array}$ & $\begin{array}{c}1.924 \\
(1.207)\end{array}$ \\
\hline Young*Immigrant & $\begin{array}{c}6.383 \\
(1.947)\end{array}$ & $\begin{array}{c}4.899 \\
(2.362)\end{array}$ & $\begin{array}{c}3.862 \\
(2.274)\end{array}$ \\
\hline \multicolumn{4}{|c|}{ Copyright or Trademark } \\
\hline Old*Immigrant & $\begin{array}{l}-2.572 \\
(1.719)\end{array}$ & $\begin{array}{l}-0.127 \\
(1.965)\end{array}$ & $\begin{array}{l}-2.165 \\
(1.938)\end{array}$ \\
\hline Young*Native & $\begin{array}{l}-2.186 \\
(1.142)\end{array}$ & $\begin{array}{l}-3.296 \\
(1.187)\end{array}$ & $\begin{array}{l}-3.780 \\
(1.147)\end{array}$ \\
\hline Young*Immigrant & $\begin{array}{l}-7.064 \\
(1.581)\end{array}$ & $\begin{array}{l}-4.577 \\
(1.985)\end{array}$ & $\begin{array}{l}-6.434 \\
(1.900)\end{array}$ \\
\hline \multicolumn{4}{|c|}{ Patents (granted or pending) } \\
\hline Old*Immigrant & $\begin{array}{c}3.756 \\
(1.252)\end{array}$ & $\begin{array}{c}1.582 \\
(1.302)\end{array}$ & $\begin{array}{c}0.490 \\
(1.246)\end{array}$ \\
\hline Young*Native & $\begin{array}{c}0.464 \\
(0.684)\end{array}$ & $\begin{array}{c}0.848 \\
(0.709)\end{array}$ & $\begin{array}{c}0.284 \\
(0.675)\end{array}$ \\
\hline Young*Immigrant & $\begin{array}{c}1.336 \\
(1.099) \\
\end{array}$ & $\begin{array}{r}-0.069 \\
(1.331)\end{array}$ & $\begin{array}{l}-0.951 \\
(1.235)\end{array}$ \\
\hline Observations & 11,000 & 11,000 & 11,000 \\
\hline
\end{tabular}

Note: Results from LPM estimation of Equation (1) at firm age 1. Coefficients and standard errors are multiplied by 100 for ease of reading. All regressions include firm age and age squared. The second column ("+ Demographics") includes demographic variables (gender, age, and race/ethnicity), proxies for human capital (education, veteran, and prior business), and ownership team variables (size and family relationships). The last column includes motivations from Table 2, start-up finance from Table 3, and 4-digit NAICS industry dummies from Table 4. Standard errors clustered by firm are in parentheses. 
Table 9A. Innovation by Immigrants - Education Heterogeneity

\begin{tabular}{lccc}
\hline \multicolumn{1}{c}{ VARIABLES } & Base & + Demographics & $\begin{array}{c}\text { + Motivations, } \\
\text { Finance \& Industry }\end{array}$ \\
\hline Innovation dummy & & & \\
Below BA*Immigrant & 6.834 & 6.655 & 3.921 \\
BA*Native & $(4.056)$ & $(4.003)$ & $(3.809)$ \\
& 3.273 & 1.887 & 0.878 \\
BA*Immigrant & $(1.487)$ & $(1.493)$ & $(1.439)$ \\
& 4.472 & 6.105 & 3.225 \\
Graduate*Native & $(2.456)$ & $(2.664)$ & $(2.556)$ \\
& 4.681 & 4.089 & 2.181 \\
Graduate*Immigrant & $(1.664)$ & $(1.684)$ & $(1.639)$ \\
Innovation count & 6.288 & 7.503 & 4.405 \\
Below BA*Immigrant & $(2.155)$ & $(2.468)$ & $(2.428)$ \\
BA*Native & & & 0.119 \\
& 0.180 & 0.186 & $(0.077)$ \\
BA*Immigrant & $(0.081)$ & $(0.081)$ & 0.068 \\
& 0.119 & 0.087 & $(0.030)$ \\
Graduate*Native & $(0.033)$ & $(0.033)$ & 0.070 \\
Graduate*Immigrant & 0.081 & 0.150 & $(0.056)$ \\
& $(0.053)$ & $(0.058)$ & 0.087 \\
Observations & 0.117 & 0.114 & $(0.034)$ \\
\hline N & $(0.036)$ & $(0.036)$ & 0.218 \\
& 0.241 & 0.302 & $(0.049)$ \\
\hline
\end{tabular}

Note: Results from LPM estimation of Equation (1) at firm age 1. Coefficients and standard errors are multiplied by 100 for ease of reading. All regressions include firm age and age squared. The second column ("+ Demographics") includes demographic variables (gender, age, and race/ethnicity), proxies for human capital (education, veteran, and prior business), and ownership team variables (size and family relationships). The last column includes motivations from Table 2, start-up finance from Table 3, and 4-digit NAICS industry dummies from Table 4. Standard errors clustered by firm are in parentheses. 
Table 9B. R\&D, Copyright, Trademark, and Patents by Immigrants - Education Heterogeneity

\begin{tabular}{|c|c|c|c|}
\hline VARIABLES & Base & + Demographics & $\begin{array}{c}\text { + Motivations, } \\
\text { Finance \& Industry }\end{array}$ \\
\hline \multicolumn{4}{|l|}{ R\&D activity (any type) } \\
\hline \multirow[t]{2}{*}{ Below BA*Immigrant } & 6.141 & 5.916 & 5.498 \\
\hline & $(3.662)$ & $(3.762)$ & $(3.747)$ \\
\hline \multirow[t]{2}{*}{ BA*Native } & 4.738 & 4.037 & 2.988 \\
\hline & $(1.164)$ & $(1.178)$ & $(1.145)$ \\
\hline \multirow[t]{2}{*}{ BA*Immigrant } & 3.350 & 6.395 & 4.245 \\
\hline & $(2.011)$ & $(2.376)$ & $(2.261)$ \\
\hline \multirow[t]{2}{*}{ Graduate*Native } & 16.89 & 15.62 & 11.94 \\
\hline & $(1.473)$ & $(1.485)$ & $(1.429)$ \\
\hline \multirow[t]{2}{*}{ Graduate*Immigrant } & 19.86 & 21.76 & 17.27 \\
\hline & (2.099) & $(2.432)$ & $(2.328)$ \\
\hline \multicolumn{4}{|l|}{ Copyright or Trademark } \\
\hline \multirow[t]{2}{*}{ Below BA*Immigrant } & 2.493 & 3.522 & 1.435 \\
\hline & $(3.337)$ & $(3.398)$ & $(3.241)$ \\
\hline \multirow[t]{2}{*}{ BA*Native } & 5.151 & 4.248 & 3.049 \\
\hline & $(1.190)$ & $(1.192)$ & $(1.142)$ \\
\hline \multirow[t]{2}{*}{ BA*Immigrant } & -2.528 & 2.411 & -0.421 \\
\hline & $(1.725)$ & $(2.043)$ & (1.998) \\
\hline \multirow[t]{2}{*}{ Graduate*Native } & 10.46 & 9.201 & 7.876 \\
\hline & $(1.423)$ & $(1.425)$ & $(1.375)$ \\
\hline \multirow[t]{2}{*}{ Graduate*Immigrant } & 4.867 & 8.811 & 5.640 \\
\hline & $(1.803)$ & $(2.151)$ & $(2.091)$ \\
\hline Observations & 11,000 & 11,000 & 11,000 \\
\hline
\end{tabular}

Note: Results from LPM estimation of Equation (1) at firm age 1. Coefficients and standard errors are multiplied by 100 for ease of reading. All regressions include firm age and age squared. The second column ("+ Demographics") includes demographic variables (gender, age, and race/ethnicity), proxies for human capital (education, veteran, and prior business), and ownership team variables (size and family relationships). The last column includes motivations from Table 2, start-up finance from Table 3, and 4-digit NAICS industry dummies from Table 4. Standard errors clustered by firm are in parentheses. 
Table 10A. Innovation by Immigrants - Race Heterogeneity

\begin{tabular}{|c|c|c|c|}
\hline VARIABLES & Base & + Demographics & $\begin{array}{l}\text { + Motivations, } \\
\text { Finance \& Industry }\end{array}$ \\
\hline \multicolumn{4}{|l|}{ Innovation dummy } \\
\hline \multirow[t]{2}{*}{ Hispanic*Immigrant } & -1.417 & -1.955 & -1.735 \\
\hline & $(5.235)$ & $(5.119)$ & $(4.932)$ \\
\hline \multirow[t]{2}{*}{ White*Immigrant } & 6.816 & 6.111 & 4.101 \\
\hline & $(2.135)$ & $(2.162)$ & $(2.088)$ \\
\hline \multirow[t]{2}{*}{ Asian Indian*Immigrant } & 0.474 & -0.320 & -4.872 \\
\hline & $(2.394)$ & $(2.478)$ & $(2.488)$ \\
\hline \multirow[t]{2}{*}{ Chinese*Immigrant } & 5.087 & 4.170 & 0.628 \\
\hline & $(4.126)$ & $(4.053)$ & $(4.047)$ \\
\hline \multirow[t]{2}{*}{ Other Asian*Immigrant } & -0.819 & -1.831 & -3.927 \\
\hline & $(4.428)$ & $(4.437)$ & $(4.222)$ \\
\hline \multirow[t]{2}{*}{ Other Minority*Immigrant } & 1.046 & 0.249 & -4.786 \\
\hline & $(7.565)$ & $(7.353)$ & $(7.141)$ \\
\hline \multicolumn{4}{|l|}{ Innovation count } \\
\hline \multirow[t]{2}{*}{ Hispanic*Immigrant } & 0.031 & 0.017 & 0.014 \\
\hline & $(0.113)$ & $(0.106)$ & $(0.100)$ \\
\hline \multirow[t]{2}{*}{ White*Immigrant } & 0.217 & 0.204 & 0.132 \\
\hline & $(0.042)$ & $(0.042)$ & $(0.041)$ \\
\hline \multirow[t]{2}{*}{ Asian Indian*Immigrant } & 0.008 & -0.025 & -0.172 \\
\hline & $(0.052)$ & $(0.053)$ & $(0.051)$ \\
\hline \multirow[t]{2}{*}{ Chinese*Immigrant } & 0.143 & 0.133 & 0.024 \\
\hline & $(0.088)$ & $(0.084)$ & $(0.081)$ \\
\hline \multirow[t]{2}{*}{ Other Asian*Immigrant } & -0.079 & -0.108 & -0.156 \\
\hline & $(0.092)$ & $(0.090)$ & $(0.089)$ \\
\hline \multirow[t]{2}{*}{ Other Minority*Immigrant } & -0.056 & -0.072 & -0.238 \\
\hline & $(0.174)$ & $(0.165)$ & $(0.170)$ \\
\hline Observations & 11,000 & 11,000 & 11,000 \\
\hline
\end{tabular}

Note: Results from LPM estimation of Equation (1) at firm age 1. Coefficients and standard errors are multiplied by 100 for ease of reading. All regressions include firm age and age squared. The second column ("+ Demographics") includes demographic variables (gender, age, and race/ethnicity), proxies for human capital (education, veteran, and prior business), and ownership team variables (size and family relationships). The last column includes motivations from Table 2, start-up finance from Table 3, and 4-digit NAICS industry dummies from Table 4. Standard errors clustered by firm are in parentheses. 
Table 10B. R\&D, Copyright, Trademark, and Patents by Immigrants - Race Heterogeneity

\begin{tabular}{lccc}
\hline \multicolumn{1}{c}{ VARIABLES } & Base & + Demographics & $\begin{array}{c}\text { + Motivations, } \\
\text { Finance \& Industry }\end{array}$ \\
\hline R\&D activity (any type) & 1.493 & -0.645 & 1.376 \\
Hispanic*Immigrant & $(4.612)$ & $(4.575)$ & $(4.290)$ \\
& 12.99 & 9.360 & 8.009 \\
White*Immigrant & $(2.329)$ & $(2.291)$ & $(2.184)$ \\
& -0.457 & -4.143 & -5.077 \\
Asian Indian*Immigrant & $(2.175)$ & $(2.185)$ & $(2.160)$ \\
& 13.54 & 7.047 & 3.559 \\
Chinese*Immigrant & $(4.441)$ & $(4.287)$ & $(3.892)$ \\
& -2.030 & -3.537 & -5.770 \\
Other Asian*Immigrant & $(3.636)$ & $(3.521)$ & $(3.112)$ \\
& -0.107 & -3.195 & -6.906 \\
Other Minority*Immigrant & $(6.737)$ & $(6.292)$ & $(6.233)$ \\
& & & -5.087 \\
Copyright or Trademark & -4.912 & -6.061 & $(3.843)$ \\
Hispanic*Immigrant & $(3.841)$ & $(3.797)$ & -0.095 \\
& 4.280 & 2.592 & $(1.975)$ \\
White*Immigrant & $(2.097)$ & $(2.064)$ & -11.94 \\
& -9.049 & -10.02 & $(1.784)$ \\
Asian Indian*Immigrant & $(1.625)$ & $(1.685)$ & -4.284 \\
& 0.486 & -2.116 & $(3.578)$ \\
Chinese*Immigrant & $(3.749)$ & $(3.672)$ & -9.797 \\
& -8.466 & -9.400 & $(2.636)$ \\
Other Asian*Immigrant & $(2.863)$ & $(2.766)$ & $\mathrm{D}$ \\
& $\mathrm{D}$ & $\mathrm{D}$ & 11,000 \\
Other Minority*Immigrant & & 11,000 & \\
& 11,000 & & \\
\hline Observations & & & \\
\hline
\end{tabular}

Note: Results from LPM estimation of Equation (1) at firm age 1. Coefficients and standard errors are multiplied by 100 for ease of reading. All regressions include firm age and age squared. The second column ("+ Demographics") includes demographic variables (gender, age, and race/ethnicity), proxies for human capital (education, veteran, and prior business), and ownership team variables (size and family relationships). The last column includes motivations from Table 2, start-up finance from Table 3, and 4-digit NAICS industry dummies from Table 4. Standard errors clustered by firm are in parentheses. " $D$ " means suppressed to ensure that no confidential information is disclosed. 